$\begin{array}{lllllllll}\mathbf{A} & \mathbf{R} & \mathbf{T} & \mathbf{Y} & \mathbf{K} & \mathbf{U} & \mathbf{L} & \mathbf{Y}\end{array}$

Collactanea Theologica

$85(2015) \mathrm{nr} 2$

BOGDAN PONIŻY, POZNAŃ

\title{
NOWE SPOJRZENIE NA HISTORYCZNY KONTEKST KSIĘGI MĄDROŚCI
}

\section{Wcześniejsze próby ustalenia czasu powstania Księgi Mądrości ${ }^{1}$}

Księga Mądrości znajduje się tuż za księgami: Psalmów, Przysłów, Koheleta i Pieśnią nad Pieśniami, a przed Mądrością Syracha. A więc została włączona do nurtu Ksiąg mądrościowych. ${ }^{2}$ Takie usytuowanie wydaje się oczywiste - Księga Mądrości mówi bowiem o Mądrości Bożej i o prześladowaniu człowieka sprawiedliwego, a są to dwa tematy bardzo popularne w literaturze mądrościowej tamtego okresu. Przez długi czas wydawało się, że wyłącznie taki zamysł przyświecał autorowi tej księgi.

Egzegeci wielokrotnie podejmowali próby dokładnego ustalenia czasu powstania Księgi Mądrości. Wytyczone granice czasowe były bardzo szerokie: jako moment a quo uznawano zatem powstanie greckiego tłumaczenia Starego Testamentu, czyli Septuaginty, za moment ad quem czasy Filona Aleksandryjskiego. ${ }^{3}$ Hipotez było wiele, skoro jednak księga uznana została za księgę mądrościową,

1 Zagadnienie to zostało szeroko omówione w: B. P o n i ż y, Księga Mądrości, Nowy Komentarz Biblijny, t. XX, Edycja św. Pawła, Częstochowa 2012, s. 28-40; t e n ż e, Kiedy powstała Księga Mądrości w: W. C h r o s t o w s k i (oprac.), Stowo Twoje jest Prawdą. Księga Pamiątkowa dla Księdza Profesora Stanisława Mędali CM w 65. rocznice urodzin. Warszawa, 2000, s. 264-277.

2 Księga Mądrości powstała poza Palestyną, i dlatego Żydzi jej nie uznają i nie weszła w skład Biblii Hebrajskiej. To ciągłe podważanie przez Żydów palestyńskich jej autentyczności sprawiło, że do Pisma Świętego chrześcijan została przyjęta jak gdyby w „drugiej kolejności”, dlatego należała do ksiąg deuterokanonicznych. Zatwierdził to swoim autorytetem Sobór Trydencki w 1546 r.

3 Ur. ok. 15 r. przed Chr. zm. ok. 54 r. po Chr. 
nie miało to tak wielkiego znaczenia. Mądrościowe pouczenia mają zwykle naturę ogólną, nie potrzebują ani czasu, ani miejsca akcji. Przy poszukiwaniu dowodów, które umożliwiłyby konkretną już datację Księgi Mądrości, egzegeci starali się ustalić przede wszystkim, kim był jej autor oraz jakie jest miejsce jej powstania, a także język. Księga Mądrości jednak, mimo że pochodzi z czasów nie tak odległych - ok. 2000 lat temu - pozostawała księgą pełną tajemnic.

$\mathrm{Na}$ podstawie analizy treści, struktury i słownictwa Księgi Mądrości ustalono zatem, że jej autorem jest Żyd, a język grecki jest jej językiem oryginalnym, choć ze względu na wiele elementów retoryki hebrajskiej (m.in. paralelizmy, struktury koncentryczne) poszukiwano też pierwowzoru w języku hebrajskim. Nigdy go jednak nie znaleziono. Tak więc autorem Księgi Mądrości jest zapewne Żyd mówiący już po grecku, co było zjawiskiem bardzo częstym w świecie śródziemnomorskim, zhellenizowanym po podbojach Aleksandra Wielkiego. Musiał on być człowiekiem wykształconym i to zarówno w kulturze żydowskiej jak i greckiej. A więc żył na styku tych dwóch światów. To z kolei wskazuje na miejsce powstania księgi - największą diasporę żydowską w Egipcie, która znajdowała się w Aleksandrii.

Pogłębiona analiza słownictwa Księgi Mądrości pomogła też usytuować ją w czasie. Zastosowane przez jej autora terminy pozwalają - przez porównanie z innymi dziełami pisanymi w konkretnym okresie - ustalić jej datację. ${ }^{4}$ Bardzo istotne są tu badania, M. Gilberta, ${ }^{5}$ G. Scarpata i dwóch egzegetów protestanckich D. Winstona i S. Cheona ${ }^{6}$

4 Argumentem za hipotezą późniejszego powstania księgi jest użycie w tekście ok. 40 terminów, które nie występowały wcześniej, a granicą jest 30 r. przed Chr.

5 M. Gi 1 b e r t, La critique des dieux dans le Livre de la Sagesse (Sg 13-15), Rome 1973; G. S c a r p a t, Libro della Sapienza.Testo, traduzione,introduzione e commento, t. I-III, Brescia 1989-1999.

6 Zwracają oni szczególną uwagę na pięć terminów wskazujących na

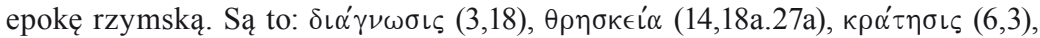
$\mu\left\llcorner\sigma o \xi \in \nu \iota^{\prime} \alpha(19,13), \sigma \epsilon ́ \beta \alpha \sigma \mu \alpha(14,20 \mathrm{~b} ; 15,17 \mathrm{~b})\right.$. Na podstawie realiów specyficznych dla imperium rzymskiego oraz wielu świadectw tekstualnych tę właśnie tę epokę 
Badania D. Winstona, zawarte $\mathrm{w}$ jego pracy The Wisdom of Solomon. A New Translation with Introduction and Commentary (New York 1984), a szczególnie analiza lingwistyczna użytych w Księdze Mądrości terminów wskazuje, że czasem jej powstania jest epoka rzymskiego cesarza Gajusza Kaliguli. Termin, który w określeniu datacji Księgi Mądrości ma kluczowe znaczenie, to

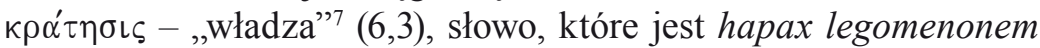
w Księdze Mądrości, i nigdzie poza nią w Starym Testamencie nie występuje. Było ono bardzo charakterystyczne dla epoki panowania Rzymian w Egipcie, a rozpoczęła się ona 1 sierpnia 30 r. przed Chr. A więc Księga Mądrości musiała powstać już po tej dacie. Drugą wskazówką jest nawiązanie do aktualnych wydarzeń w diasporze aleksandryjskiej, a zatem do sytuacji, w której prześladowano Żydów. Te spostrzeżenia Winstona, skłoniły innego egzegetę z kręgów protestanckich, S. Cheona ${ }^{8}$ do poszukiwania dalszych argumentów za późniejszym niż dotąd zakładano czasem napisania Księgi Mądrości. Cheon wykazał, że przedstawione w Księdze Mądrości wydarzenia są bardzo podobne do opisu historii prześladowań Żydów w Aleksandrii w 38 r. po Chr., które przedstawia Filon Aleksandryjski w swoich dwóch dziełach Flakkus i Poselstwo do Gajusza.

przyjmują jako najprawdopodobniejszy kontekst powstania dzieła. Zastosowanie

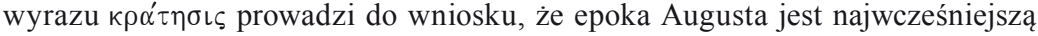
granicą czasową, użycie zaś słowa dia,gnwsij odsyła do ok. połowy I w. po Chr., a więc czasów Klaudiusza. Nie znajdujemy bowiem innych świadectw potwierdzających w czasach wcześniejszych użycia tego terminu; zob. B. P o n i ż y, Księga Mądrości, s. 33,37; por. tamże, s. 28-40.

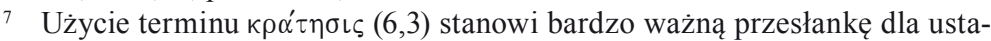
lenia datacji Księgi Mądrości. 1 VIII 30 r. przed Chr. rzymskie wojska podbiły Egipt. Rzym uznał tę datę za nadprzyrodzony znak, gdyż tego dnia przypadało święto Victoria Virgo. Niezależnie od dotychczasowego kalendarza, wprowadzono dodatkowo kalendarz rzymski. Lata panowania Augusta liczono od sierpnia $30 \mathrm{r}$. pierwszego dnia miesiąca thoth. Jak poświadcza dekret senatu: „Dzień, w którym Aleksandria została zdobyta, był szczęśliwy” i został uznany za początek nowego czasu; zob. tamże, s. 34.

8 S. C h é o n, The Exodus Story in the Wisdom of Solomon, 1997.

9 B. P o n i ż y, Kiedy powstała Księga Mądrości, s. 276-277. 
Takie przesunięcie czasu powstania Księgi Mądrości - z ok. III w. przed Chr. na pierwszą połowę I w. po Chr., a najprawdopodobniej na 38 r., czyli datę pierwszego pogromu Żydów w Aleksandrii ma niezwykle istotne znaczenie. Z punktu widzenia chronologii Księga Mądrości staje się bowiem nie tylko ostatnią księgą Starego Testamentu, ale księgą prawie równoległą do nauczania Chrystusa i współczesną pierwszemu Kościołowi.

Sytuując Księgę Mądrości w 38 r., albo wkrótce potem, zmieniamy nie tylko historyczny jej kontekst, ale także przesłanie. Przestaje ona być jedynie księgą mądrościową, ale staje się księgą o wielkim znaczeniu historycznym, która w sposób zakamuflowany opowiada o cierpieniach Żydów podczas pierwszego pogromu w Aleksandrii. Napisana jest tak żywo i obrazowo, z takim ładunkiem emocjonalnym, że można zaryzykować twierdzenie, iż powstała bezpośrednio po tych prześladowaniach, albo nawet w czasie ich trwania.

\section{Dzieło Filona Aleksandryjskiego jako historyczny kontekst wydarzeń przedstawionych w Księdze Mądrości}

Wydany niedawno, w 2012 r., pierwszy polski przekład dzieła Filona Aleksandryjskiego Flakkus. Pierwszy pogrom Żydów $w$ Aleksandrii ${ }^{10} \mathrm{z}$ niezwykle dopracowanym komentarzem dokładnie opisuje dzieje tych prześladowań.

Warto zatem przyjrzeć się, jaki był rzeczywiście historyczny kontekst wydarzeń opisanych w Księdze Mądrości. Spróbujmy pod tekst księgi podłożyć, jak kanwę, dzieło Filona. Księga Mądrości nabierze wtedy zupełnie nowego wymiaru. A ujmując to w sposób obrazowy, przestanie dryfować po morzu historii, zarzuci kotwicę w określonym miejscu i czasie. Nie tylko lepiej będzie można rozumieć mądrościowe jej przesłanie, ale jednocześnie stanie się ona „krzykiem serca” cierpiącego narodu żydowskiego, duchowym testamentem autora.

${ }_{10}$ Filon z A leksandri, Flakkus. Pierwszy pogrom Żydów w Aleksandrii, tłum. E. O s e k, Wydawnictwo WAM, Kraków 2012. 
Głównym tematem Księgi Mądrości jest Mądrość. Ale w ten temat ogólny wpleciona jest dramatyczna opowieść o losach człowieka sprawiedliwego, którego prześladują $\alpha \dot{\sigma} \epsilon \beta \in i \varsigma$ („bezbożni”).

\section{Czas i miejsce wydarzeń}

Miejscem akcji jest Aleksandria. Czasem akcji: rok 38 po Chr. Bohaterami dramatu - prześladowany Żyd, reprezentujący całą społeczność żydowską w Aleksandrii, i prześladowcy - $\alpha \sigma \in \beta \in i \varsigma$ (,bezbożni”), czyli bojówki greckie w Aleksandrii.

Aleksandria - doskonale położony, największy port handlowy ówczesnego świata. Stąd bogactwa Egiptu można było transportować do Grecji i Italii i do wszystkich krajów śródziemnomorskich. Pełne atrakcji, niewyobrażalnie bogate miasto. Jednocześnie było to centrum nauki, sztuki i literatury. W Aleksandrii mieszkali w miarę zgodnie Grecy, Żydzi i Egipcjanie. Grecy mieli status obywateli, ludność podbita, czyli Egipcjanie, nie mieli żadnych praw, natomiast Żydzi stanowili grupę pośrednią. Nie było im jednak tutaj tak źle, skoro ludności żydowskiej w Aleksandrii było w owym czasie więcej niż w Jerozolimie.

W diasporze aleksandryjskiej, tak zresztą jak wszędzie, Żydzi zachowywali swoją odrębność. Tworzyli nawet własną strukturę społeczną - politeumę. Domagali się odzyskania pełni praw, jakie mieli za Aleksandra Wielkiego. Jednak przede wszystkim pragnęli zachować swoją religię: dla nich, jako dla monoteistów, politeizm Greków był nie do przyjęcia, a elementy zoolatrii we wierzeniach Egipcjan - odrażające.

Z dzieł Filona Aleksandryjskiego: Flakkus i Poselstwo do Gajusza, wiadomo, że do czasu pogromu w 38 r. po Chr. Żydzi mieli prawo mieszkać we wszystkich pięciu dzielnicach Aleksandrii. W każdej z nich znajdowało się wiele żydowskich domów modlitwy, które były dla nich także miejscami zebrań. Największa, główna synagoga znajdowała się w pobliżu jednego z gimnazjonów. Filon odnotowuje też obecność wielu świątyń pogańskich we wszystkich 
dzielnicach Aleksandrii. ${ }^{11}$ Spośród nich wymienia i opisuje z nazwy tylko Sebastejon, czyli świątynię Augusta największą i najwspanialszą świątynię kultu cesarskiego ówczesnego świata.

Jak pisze Filon, ${ }^{12}$ Aleksandria była miastem kosmopolitycznym, skupiającym w sobie wiele wspólnot etnicznych, takich jak Grecy, Macedończycy, Egipcjanie, Żydzi, Celtowie, Trakowie, Ilirowie, Persowie, Arabowie. Królowie z dynastii Ptolemeuszy przez 300 lat swoich rządów (323-30 przed Chr.). przyznawali poszczególnych mniejszościom etnicznym nie tylko w Aleksandrii, ale też w innych miastach Egiptu, pewnego rodzaju autonomię. ${ }^{13}$ Nawet jeśli jakaś grupa etniczna miała tak specyficzne zwyczaje i religię jak Żydzi, Ptolemeusze odnosili się do nich tolerancyjnie. Filon podkreśla, że zawsze respektowali zakaz umieszczania obrazów i posągów w żydowskich synagogach. ${ }^{14}$

Podbój Aleksandrii i Egiptu dokonany w 30 r. przed Chr. przez Rzymian nie zmienił polityki religijnej tolerancji. Oktawian August zaraz na początku swoich rządów w Egipcie potwierdził wszystkie prawa, jakimi Żydzi cieszyli się za rządów Ptolemeuszy. ${ }^{15} \mathrm{~W}$ samym centrum Aleksandrii miała się wznosić kolumna z wyrytym tekstem edyktu, na mocy którego władze rzymskie gwarantowały Żydom wolność religijną i możność życia według narodowych zwyczajów. August zapewniał Żydom pełną wolność kultu i zbierania się w synagogach. ${ }^{16}$ Szczególnie istotne dla Żydów były postanowienia dotyczące synagog, które nazywano domami modlitwy lub miejscami zgromadzeń: w Liście do namiestników Azji cesarz zakazał zgromadzeń wszystkim stowarzyszeniom religijnym, z wyjątkiem żydowskich synagog, które nazwał „,szkołami cnoty i sprawiedliwości”. ${ }^{7}$

\footnotetext{
11 Tamże, 51.

12 Tamże, 120.

13 Te n ż e, List Arysteasza, 310.

14 Tamże, 310.

15 Te n ż e, Flakkus. 124.

16 Te n ż e, Poselstwo do Gajusza, 143-158, 311-318.

17 Te nż e, Flakkus. 41, 45, 4-49, 53.
} 
Całkowitym przeciwieństwem synagog, gdzie zbierała się społeczność żydowska, były bardzo popularne wśród bogatych Greków tzw. kluby w Aleksandrii. „Kluby” oficjalnie były stowarzyszeniami religijnymi zawiązanymi w tym celu, by odbywać wspólne uczty ofiarne na cześć egipskich bogów, nieformalnie - partiami politycznymi, których członkowie tworzyli bojówki, terroryzujące miasto i stanowiące zagrożenie dla porządku publicznego. ${ }^{18} \mathrm{Ci}$ właśnie członkowie pijackich stowarzyszeń wywarli presję na Flakkusie, który w owym czasie sprawował w Egipcie władzę rzymskiego namiestnika, prowokując go do antyżydowskich działań. ${ }^{19}$

Oddajmy głos Filonowi: „Istnieją w mieście koterie, liczące wielu członków. Nie są oparte na żadnej zdrowej zasadzie ani wspólnocie interesów. Jednoczy je mocne wino, ${ }^{20}$ pijaństwo, pijackie wybryki oraz ich wspólna córka: arogancja. Miejscowi nazywają je «klubami» $\mathrm{i}$ «bankietami». We wszystkich tych klubach albo przynajmniej w większości z nich prym wiódł Izydor. Nazywano go «królem uczty», «mistrzem ceremonii biesiadnej», «człowiekiem, który trzęsie miastem». Na jeden jego sygnał - ilekroć decydował się na jakiś eksces - wszyscy członkowie klubów zbierali się, mówili i czynili wszystko, cokolwiek im kazał". ${ }^{21}$

Początek prześladowań w diasporze aleksandryjskiej

Kiedy do Aleksandrii przybył przyjaciel i delegat nowego cesarza Gajusza Kaliguli, Agryppa I, Żydzi przyszli do niego, by złożyć skargę na namiestnika Flakkusa. Spotkanie, tak jak wszystkie zebrania mieszkańców z rzymskim namiestnikiem, odbyło się w amfiteatrze, położonym tuż obok agory. Podczas spotkania greccy

18 Tamże, 4, 19, 65, 69,128, 135-145.

19 Zob. E. O s e k, Wprowadzenie, przekład i komentarz do dzieła Filona z Aleksandrii „Flakkus”, w: Filon z Aleksandrii, Flakkus. Pierwszy pogrom Żydów w Aleksandrii, s. 55.

20 Nierozcieńczone wodą.

${ }^{21}$ Filon z Aleksandrii, Flakkus, 136, 137. 
prowokatorzy specjalnie publicznie obrazili Agryppę, ponieważ był żydowskiego pochodzenia. ${ }^{22}$ Stało się to sygnałem do rozpoczęcia ataku na ludność żydowską. Flakkus, nie tylko nie stanął po stronie delegata rzymskiego cesarza, ale ogłosił edykt, w którym nazwał Żydów „cudzoziemcami i obcymi”, co było rażąco sprzeczne $\mathrm{z}$ jego dotychczasowym postępowaniem i stylem rządzenia. ${ }^{23}$ Aleksandryjscy Żydzi stracili więc prawo do politeumy i związane z tym przywileje prawne. Prawo przestało ich chronić. Było to w 38 r. po Chr.

Filon z Aleksandrii tak komentuje postanowienie Flakkusa: „Namiestnik wydaje edykt, w którym ogłasza nas cudzoziemcami i imigrantami. Skazuje nas bez sądu, nie dając żadnej możliwości obrony. Zostaje oskarżycielem, świadkiem, sędzią i katem w jednej osobie. (...) Do dwóch poprzednich aktów bezprawia dodaje też trzeci, pozwalając każdemu, kto chce, grabić Żydów i traktować nas jak jeńców podczas zdobycia nieprzyjacielskiego miasta". 24

W czasie pogromu Żydzi przeżyli prawdziwe piekło. Napastnicy profanowali synagogi, umieszczając w nich posągi nowego cesarza Kaliguli, który ogłosił się bogiem. Jednak nie wydał żadnego specjalnego edyktu zmuszającego Żydów do uczestnictwa w tym kulcie, dlatego działania te były całkowicie bezprawne. Niszczono żydowskie domy i sklepy. Wszystkich Żydów zamknięto w jednej, najmniejszej dzielnicy Aleksandrii, którą zajmowali na samym początku. Znajdowała się ona na peryferiach miasta tuż obok wysypiska śmieci. Stała się w ten sposób pierwszym żydowskim gettem. Aresztowanych zostało 38 członków Rady Starszych, tzw. geruzji, 25

22 Herod Agryppa I (11/10 przed Chr. - 44 po Chr.) był wnukiem Heroda Wielkiego.

${ }^{23}$ Po objęciu władzy przez Kaligulę, Flakkus zaczął obawiać się jego zemsty, bowiem podczas procesu matki cesarza, Agrypiny, wypowiadał się w sądzie przeciwko niej. Dlatego rozpaczliwie poszukiwał sprzymierzeńców i znalazł ich we wrogo nastawionych do Żydów Aleksandryjczykach.

${ }^{24}$ Filon z Aleksandrii, Flakkus, 53.

25 Wszyscy, których zastano wtedy w domach. Rada Starszych liczyła 70 członków. 
i w wielkim aleksandryjskim amfiteatrze podczas widowiska z okazji urodzin Kaliguli, przypadających 31 sierpnia, zostali oni publicznie poddani torturom. „Brak odpowiednich słów - pisze Filon - aby oddać stopień okrucieństwa, jakimi się odznaczały". ${ }^{26} \mathrm{Na}$ ulicach bito i napastowano Żydów. Zamieszki ustały dopiero w październiku 38 r. po Chr., kiedy rzymscy żołnierze aresztowali Flakkusa.

Właśnie w czasie tych prześladowań Żydów w Aleksandrii - według dzisiejszych egzegetów - została napisana Księga Mądrości. I to one stają się kluczem do zrozumienia tej księgi.

\section{Księga Mądrości na tle pogromu Żydów w Aleksandrii - 38 r.}

Księga rozpoczyna się gorącym apelem 'A $\gamma \alpha \pi \eta ́ \sigma \alpha \tau \epsilon ~ \delta\llcorner\kappa \alpha\llcorner\circ \sigma u ́ \nu \eta \nu-$ „Umiłujcie sprawiedliwość” $(1,1)$. Ta apostrofa skierowana jest do „sędziów ziemskich”, czyli tych, którzy sprawują władzę. Jest więc wołaniem o sprawiedliwość. Podobnie w czasach współczesnych Żydzi upominali się o sprawiedliwość po Holocauście, jaki stał się ich udziałem w II wojnie światowej.

Fragment następny 1,2 - 2,20 mówi o tym, że Boga nie można wystawiać na próbę. Taka postawa zawsze była piętnowana w Biblii: człowiek świadomie postępuje źle i bezczelnie czeka, czy Bóg zainterweniuje, czy nie. Chodzi tu o przewrotność myśli, tak obcą zalecanej w Biblii, prostocie serca. W tej części księgi jest też zawarta zapowiedź kary, a będzie nią śmierć. Śmierć ukazana jest inaczej niż rozumiemy ją dzisiaj, ponieważ nieśmiertelność ma być udziałem tylko sprawiedliwych. I to jest właśnie główna przyczyna - tak

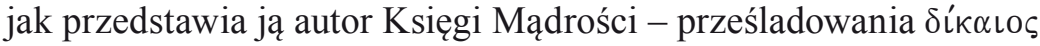

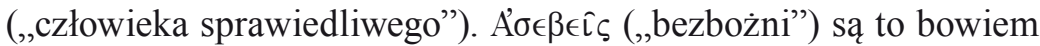
ludzie, których życie zmierza ku nicości. Z chwilą śmierci skończy się dla nich wszystko. A zatem jest to życie bez perspektywy. Życie, które przeminie bez śladu, a więc trzeba je wykorzystać do własnych celów i przyjemności. W myślach $\alpha \sigma \in \beta \in \hat{\complement} \varsigma$ pojawia się zatem przewrotny zamysł. Postanawiają „wystawić Boga na próbę”. Do tej prowokacji

26 Filon z Aleksandrii, Flakkus, 60. 
ma posłużyć człowiek sprawiedliwy. Autor Księgi Mądrości cytuje tu słowa z Izajasza: „Zróbmy zasadzkę na sprawiedliwego, bo nam niewygodny" (Iz 2,12). Dlaczego jest niewygodny? Autor wymienia przyczyny natury religijnej: życie sprawiedliwego jest „,niepodobne do innych", zarzuca bezbożnym łamanie prawa, wypomina błędy ich obyczajów, chwali się, że Bóg jest Jego Ojcem, a śmierć uważa za szczęście, bo przecież czeka go nieśmiertelność u Boga. Dlatego nawet jeśli zasądzą go na śmierć haniebną, będzie ocalony (por. 2,20). A więc bezbożni chcą sprawdzić, czy słowa sprawiedliwego są prawdziwe i czy rzeczywiście - jeśli go będą dręczyć - jego Bóg ujmie się za nim. Tym samym kuszą, prowokują, wystawiają Boga na próbę, czyniąc sobie z tego zabawę.

Autor Księgi Mądrości nie opisuje sceny męki i śmierci sprawiedliwego. Pisze piękne słowa o nieśmiertelności, do której Bóg stworzył człowieka, i o śmierci, której doświadczą należący do diabła. Śmierci, która będzie końcem wszystkiego. A potem następuje opis, jak to sprawiedliwych nie dosięgnie już męka, bo ich dusze są w ręku Boga. To tylko oczom głupich - a w Biblii określenie $\mu \alpha$ $\tau \alpha \iota \lambda \iota$ (,głupi”) jest zawsze określeniem idoli i tych, którzy oddają się idolatrii, a więc synonimem bezbożnictwa - wydaje się, że sprawiedliwi umarli, a oni przecież odpoczywają w pokoju, bo nadzieja ich ,pełna jest nieśmiertelności” $(3,4)$. A dalej mamy opis kary, jaka spadnie na bezbożnych. Warto tu zwrócić uwagę, że w opisie stanu, jakiego doświadczają sprawiedliwi, zmienia się podmiot $\mathrm{z}$ jednostkowego na zbiorowy, już nie chodzi o postać indywidualną, jak w scenie 2,10-20, ale o postać kolektywną (3,1-9). A więc nie o jednego sprawiedliwego biedaka, ale o wielu sprawiedliwych.

\section{Opis wydarzeń według Filona z Aleksandrii}

Spróbujmy pod ten opis przedstawiony przez autora Księgi Mądrości podstawić narrację wydarzeń według Filona Aleksandryjskiego.

Filon pozostawił dwie relacje przedstawiające pogrom Żydów w Aleksandrii trwający w sierpniu i wrześniu 38 r. Opis wcześniejszy i bardziej obszerny znajduje się we Flakkusie, bardziej szczery 
w Poselstwie do Gajusza. Obie relacje różnią się co do przyczyn wydarzeń i interpretacji udziału w nich rzymskiego namiestnika Flakkusa: w pierwszym utworze czynią go odpowiedzialnym za ten pogrom, w drugim natomiast ukazują go tylko jako figuranta. Te różnice wypływają z faktu, że Filon napisał Flakkusa bezpośrednio po wydarzeniach w Aleksandrii, a więc jeszcze za panowania Gajusza Kaliguli, a Poselstwo do Gajusza już po śmierci cesarza. Autor może pisać swobodnie, nie musi obawiać się konsekwencji cesarskiego gniewu. Wypowiada się zatem otwarcie, że to wrogi, nieżyczliwy stosunek zmarłego cesarza do Żydów stał się głównym powodem tych wydarzeń, bo cesarz jakby przyzwolił na te prześladowania, ponieważ ich bezpośredni inicjatorzy poczuli się bezkarni. Wzajemne animozje między Grekami, Żydami i Egipcjanami istniały przecież w Aleksandrii od zawsze. Same fakty, ukazujące cierpienia Żydów w Aleksandrii podczas prześladowań 38 r. w obu utworach ukazane są podobnie.

Podburzony motłoch, który Filon nazywa ochlokracją, rusza na żydowskie domy modlitwy i ustawia w nich posągi cesarza. Dla Żydów, którym religia zakazuje wykonywać jakiekolwiek wyobrażenia Jahwe, jest to niewyobrażalna profanacja. W żydowskich synagogach cześć należną Bogu miałby odbierać cesarz Kaligula? Rozbestwiony tłum niszczy synagogi. Potem, już po głoszeniu edyktu Flakkusa, kiedy Żydów przestaje chronić prawo, tłum zaczyna wywlekać ich z mieszkań, grabi ich mienie, niszczy domy i zapędza do najmniejszej z dzielnic Aleksandrii.

Oddajmy głos Filonowi: „Po grabieżach, wysiedleniach i brutalnych eksmisjach z największych dzielnic miasta Żydzi zostali zamknięci, można powiedzieć w murach, gdyż wokół otaczali ich sami wrogowie. Nękała ich skrajna nędza i brak środków do życia, ze zgrozą musieli też patrzeć, jak kobiety i małe dzieci na ich oczach konają z głodu, który przecież został wywołany sztucznie. Tymczasem cały kraj wokół Aleksandrii cieszył się dostatkiem i urodzajem. 
Rzeka $^{27} \mathrm{w}$ czasie przypływów nawadniała uprawne pola, a żyzna równina rodząca pszenicę wydawała niebywale obfity plon". ${ }^{28}$

Żydzi musieli więc wychodzić poza mury w poszukiwaniu żywności. Jednak ci, którzy poszli na agorę kupić coś do jedzenia, byli bestialsko mordowani przez greckie bojówki. Po tej próbie przyszła następna. Flakkus kazał aresztować 38 spośród członków żydowskiej Rady Starszych (geruzji) - tych wszystkich, których akurat zastano w domu. Każe ich związać i zaprowadzić w procesji do teatru, i tam na scenie poddaje chłoście i torturom. Niektórzy zmarli natychmiast, innych poddano jeszcze dalszym męczarniom na oczach przyglądających się temu widzów. Był to spektakl, którym „uczczono” urodziny cesarza Kaliguli. Po tym okrutnym widowisku nastąpiły przewidziane wcześniej występy artystyczne.

Oszczędzimy tutaj bardziej szczegółowej relacji. Podobnie uczynił autor Księgi Mądrości, pomijając wszystkie opisy torturowania, używając tylko dwóch słów: „męka” $(3,1)$ i „kaźń” $(3,4)$. Jak gdyby nie chciał opowiadać, że $\mathrm{w}$ rodzinnym mieście tak potraktowano jego współbraci z narodu wybranego, że spotkała ich taka hańba.

Do opisu torturowania członków geruzji na scenie aleksandryjskiego teatru, jaki znajduje się w dziele Filona, ${ }^{29}$ wydaje się najbardziej przystawać fragment Księgi Mądrości 3,1-9. Z tych wersetów bije spokój i ogromna wiara. Czas próby minął, a sprawiedliwi przeszli ją zwycięsko. W oczach $\mu \alpha^{\prime} \tau \alpha$ เoı („głupich”) ich śmierć jest uznana za nieszczęście, a odejście jest unicestwieniem (por. 3,2b-3a). A oni przecież trwają w pokoju. Bóg ich bowiem doświadczył i uznał za godnych siebie. Autor używa tu porównania: doświadczył ich ,jak złoto w tyglu” $(3,6)$, bardzo charakterystyczne dla Egiptu, w którym wydobywano ogromne ilości złota i topiono w tyglach, ustalając, jakiej jest próby. „Nadzieja ich pełna jest nieśmiertelności” $(3,4 b)$, a więc to cierpiący sprawiedliwi odnoszą zwycięstwo, a nie ich prześladowcy.

\footnotetext{
27 Nil.

${ }^{28}$ Filon z Aleksandrii, Flakkus, 62-63.

29 Tamże, 74,76.
} 
W Księdze Mądrości prześladowanie sprawiedliwego ma podłoże religijne. Sprawiedliwy, a w dalszej części sprawiedliwi ukazani są jako ci, którzy cierpią za wiarę w Boga, za swoją niezrozumiałą dla innych odrębność, za to, że [jego, ich] drogi odmienne (2,15b), za to, że nie chcą poddać się idolatrii, jaką było dla nich oddawanie boskiej czci cesarzowi $(15,4)$.

Jednak w relacji Filona pojawiają się też inne okoliczności. Oto motłoch wdziera się do opuszczonych domów i zaczyna je plądrować. Porywają mienie żydowskie, zabierają cały dobytek, a jak podkreśla Filon, „było tego wiele”. I wcale nie kryją się ze zrabowanym mieniem, traktując cudzą własność jak swoją ${ }^{30}$ Pojawia się też wzmianka, że kilku członków geruzji straciło swoje bogactwa. Natomiast u Flawiusza w opisie splądrowania świątyni jest mowa o „ogromnych ilościach złota i srebra”, ${ }^{31}$ które się tam znajdowały. Czy zatem pod pretekstem zarzutów dotyczących religii i dziwnych obrzędów nie chodziło bardziej o żydowski majątek? Historycy starożytni, w tym również Filon, wspominają, że Kaligula zabierał wszystkie majątki skazańców, a nawet skazywał zamożnych ludzi tylko po to, by przejąć ich dobra. Wielu Żydów mieszkających w Aleksandrii żyło bardzo biednie i skromnie. Ale oprócz biedaków byli też Żydzi bogaci i wpływowi: bankierzy, armatorzy, kupcy zbożowi, rzemieślnicy, właściciele ziemscy. A zatem, czy zorganizowany, nagły atak na Żydów w Aleksandrii był spowodowany wyłącznie względami religijnymi i wzajemnymi animozjami, które przecież istniały w Aleksandrii od początku, czy też był po prostu zwykłą chęcią grabieży? Ale autor Księgi Mądrości nie wymienia tego motywu.

\section{Zapowiedź Bożego sądu}

W dalszym fragmencie Mdr 4,19 - 5,23 przedstawiony jest Boży sąd. Autor używa czasu przyszłego, a więc wszystko, o czym mówi

30 Tamże, 56.

31 J. F 1 a w i u s z, Przeciw Apionowi, 76-79, 80-83. 
w tej części tekstu, jest zapowiedzią, tego, co ma nastąpić. O sprawiedliwych zadręczonych na śmierć pisze natomiast w czasie teraźniejszym - „trwają w pokoju”, a więc jest to relacja aktualna. A zatem na Bożym sądzie ma zostać wymierzona sprawiedliwość: sytuacja się odwróci, sprawiedliwy zostanie zbawiony, będzie miał „udział ze świętymi” (5,5b), a bezbożni staną się ,wstrętną padliną” $(5,19)$. Przedtem jednak odczują to, co dziś nazwalibyśmy wyrzutami sumienia, żalem i skruchą. To wszystko, co dawało im przewagę na ziemi: siła, która kiedyś nazywali ,prawem sprawiedliwości” $(2,11)$, chełpliwe bogactwo $(5,8)$ przeminęło jak cień, a oni sami przed Bogiem nie mogą się wykazać żadną oznaką cnoty. Zniszczyła ich nieprawość. W czasie przyszłym jest też ukazana interwencja Boga. To Bóg przyjdzie z pomocą prześladowanym sprawiedliwym i razem z Nim „świat będzie walczył przeciw nierozumnym” $(5,20)$, czyli bezbożnym. Jednak przyczyną tego zniszczenia nie będzie Pan, to „nieprawość spustoszy całą ziemię” (5,23c). Jak zawsze w ujęciu biblijnym, przyczyną zła jest grzech człowieka. Gniew Boga jest tylko konsekwencją grzechu.

Nauka Mądrości - Mądrość Boża a greckie wykształcenie

Patrząc na Księgę Mądrości jak na dzieło pisane w trakcie prześladowań nauka Mądrości zawarta w rozdziałach 6-9 wydaje się chwilowym odpoczynkiem przed ładunkiem emocjonalnym, zawartym w dalszych rozdziałach. Można ją odczytywać jako rozbudowaną apostrofę, modlitewny zwrot skierowany do Boga.

We fragmencie 7,15-20, autor, prosząc Boga o natchnienie, wymienia dyscypliny wiedzy, które już otrzymał dzięki Mądrości. Jest to wiedza bardzo charakterystyczna dla środowiska naukowego w Aleksandrii działającego przy świątyni Muz, w tzw. Muzejonie. Swoje prace prowadzili tu: geografowie, astronomowie, matematycy, przyrodnicy i filolodzy. Obok Muzejonu istniały ogrody: botaniczny i zoologiczny, w których zgromadzono rośliny i zwierzęta $z$ całego świata. Było tam też obserwatorium astronomiczne. Zgromadzeni w Muzejonie uczeni z całego śródziemnomorskiego 
świata utrzymywani z funduszy królewskich prowadzili swobodnie swoje prace. Wśród najbardziej znanych są: Euklides, twórca podstaw geometrii przestrzennej; Arystach z Samos, który jako pierwszy zaproponował heliocentryczny model układu słonecznego; ${ }^{32}$ Eratostenes z Cyreny, matematyk, astronom, filozof, geograf i poeta znany z tego, że wyznaczył obwód ziemi i oszacował odległość Ziemi od Słońca i Księżyca, a przy tym wybitny znawca twórczości Homera; Ktesibios z Aleksandrii, konstruktor maszyn pneumatycznych, i automatycznych zegarów i organów, działających pod wpływem strumienia wody; Archimedes z Syrakuz, genialny matematyk i fizyk, który w Aleksandrii zdobywał wykształcenie; Klaudiusz Ptolemeusz zajmujący się kartografią, autor tablic astronomicznych; medyk Galen. Tak więc autor Księgi Mądrości, chwaląc się swoim wysokim i wszechstronnym wykształceniem, wpisuje się w naukowe środowisko Aleksandrii. Przestawia się jako człowiek nie ustępujący pod tym względem wykształconym obywatelom miasta. A jednocześnie całą tę swoją ogromną wiedzę przypisuje Bogu, pouczony jest bowiem przez Mądrość, która pochodzi od Boga.

Fragment ten kończy Modlitwa, nazwana później Modlitwą Salomona (9,1-18). Jednak historycznym kontekstem tej księgi, nie są czasy Salomona, ale Aleksandria pierwszej połowy I w. po Chr.

Reinterpretacja Księgi Wyjścia - przypomnienie chwały Izraela

Rozdziały 10-19 Księgi Mądrości są poświęcone reinterpretacji Księgi Wyjścia, podporządkowane głównej zasadzie Starego Testamentu: kto czym grzeszy, tym bywa karany. Taką właśnie interpretację przedstawia autor. Na tle aktualnych wydarzeń, powrót do przeszłości, do cudownego ocalenia z niewoli egipskiej, wydaje się zrozumiały. Zamknięci w aleksandryjskim getcie Żydzi zwracają się ku przeszłości, z głęboką wiarą w cudowne wyprowadzenie z niewoli. W świetle relacji Filona - która wyraźnie ukazuje,

32 Popełnił jednak błąd, sądząc, że ruch planet odbywa się po okręgu, a nie po elipsie. 
że Żydzi nie mogą się spodziewać pomocy znikąd, ani od innych zastraszonych mieszkańców Aleksandrii, ani od rzymskiego namiestnika Flakkusa, ani od wrogo nastawionego do Żydów cesarza Kaliguli - cudowne wyprowadzenie przez Boga z niewoli wydaje się jedynym możliwym sposobem ucieczki. Rozpamiętując dawne wydarzenia, autor przekazuje swoim współbraciom nadzieję. Jednak nie jest to dokładna reminiscencja wydarzeń. Nie ma w niej żądzy odwetu, jest natomiast ogromna, niezwykle żarliwa chęć przekazania tym, którzy w obecnej chwili prześladują Żydów, że naród izraelski jest naprawdę narodem wybranym, a jego Bóg nie tylko potężny, ale miłujący. W obliczu śmiertelnego niebezpieczeństwa, autor w duchowym testamencie pragnie przekazać swoją wiarę, by prześladowcy, wyzbywszy się złości, uwierzyli w Boga Izraela. Jest to też poświadczeniem, że autor wobec tak niespodziewanej napaści ze strony Greków doskonale zdaje sobie sprawę, że były to działania sterowane, a nie prześladowania wynikające z głębokiej zastarzałej nienawiści ze strony ludności aleksandryjskiej. Autor księgi jest zhellenizowanym Żydem, doskonale zna język grecki, grecką kulturę, naukę, ma zapewne wielu przyjaciół wśród Greków. Wszelkie wcześniejsze zatargi między ludnością grecką, żydowską, egipską to zatargi drobne, typowo sąsiedzkie, wynikające z odmienności religii i obyczajów, spory o prawa obywatelskie. Ta niezwykła eksplozja gwałtu i nienawiści, jaką były prześladowania w 38 r., jest nagła, niewytłumaczalna i niezrozumiała.

Filon Aleksandryjski określa te wydarzenia słowem пó $\lambda \in \mu \circ \varsigma$ (,wojna”). „Wielka i niezapowiedziana wojna została temu narodowi wydana" - pisze w Poselstwie, ${ }^{33}$ natomiast we Flakkusie ${ }^{34}$ używa terminu ,wojna” z niejakim wahaniem, uważając to wszystko, co przytrafiło się Żydom w 38 r. po Chr., za coś znacznie gorszego niż tradycyjna wojna. ${ }^{35}$ Nie potrafiąc dobrać odpowiedniego wyrazu na określenie tego nowego i niespotykanego dotąd zjawiska, decyduje

\footnotetext{
33 Filon z Aleksandri i, Poselstwo do Gajusza. 119, 121,132.

34 Te n ż e, Flakkus, 44, 56, 59-62, 95.

35 Tamże, 59.
} 


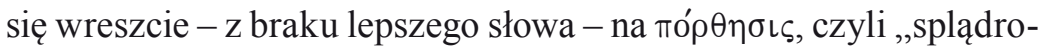
wanie i zniszczenie miasta przez nieprzyjacielską armię". ${ }^{36}$ Języki nowożytne dysponują już specjalnym terminem na określenie tego, czego starożytny autor nie umiał jeszcze nazwać. Chodzi tu o rosyjski wyraz ,pogrom". ${ }^{37}$

\section{Kult posągów jako bezpośrednia przyczyna prześladowań w Aleksandrii}

W reinterpretacji exodusu autor zamieszcza fragment, w którym krytykuje idolatrię $(13,1 b-15,19)$. Właśnie ten fragment jest niezwykle cenny w doszukiwaniu się historycznego kontekstu Księgi Mądrości. Warto tu podkreślić, że idolatria jest ukazywana w Biblii zawsze jako przyczyna wszelkiego zła. Synkretyzm religijny, panteon różnych bogów, jest dla Żyda nie do zaakceptowania. Dla Izraelitów jest tylko jeden Bóg, Jahwe, z którym łączy ich przymierze. To Bóg jest Stwórcą człowieka i dlatego Bóg musi być w życiu człowieka postawiony na pierwszym miejscu.

Do tej części nazwanej dygresją o idolatrii wprowadzają wersety 13,1-9, w których autor zamieszcza hymn na cześć Boga Stwórcy, oparty na dowodzeniu przez analogię. Dowód na istnienie Boga jest przedstawiony w taki sposób, by mogli zrozumieć go poganie. Izraelitom, którzy poznali Boga przez objawienie, taki dowód nie jest potrzebny. Historyczny kontekst Księgi Mądrości uzasadnia potrzebę przeprowadzenia takiej argumentacji. Wśród różnych dziwnych pogłosek na temat religii żydowskiej ${ }^{38}$ trzeba, by ci, którzy prześladują Żydów, lepiej ich poznali. Dowód na istnienie Boga Stwórcy oparty jest na rozumowaniu na wzór Arystotelesowego, a więc na doszukiwaniu się pierwotnej przyczyny.

36 Tamże, 56, 86-87.

37 Tego terminu używa w odniesieniu do rozruchów w 38 r. po Chr., m.in. Tcherikover 1957; Kraus-Reggiani 1984, Horst 2003; zob. E. O s e k, Wprowadzenie, przekład i komentarz do dzieła Filona z Aleksandrii ,Flakkus”, s. 41.

38 Wiele z tych zarzutów było jednak prawdziwych. 
Zaraz po tym fragmencie następuje ostra krytyka idolatrii 13,10 14,21. Człowiek sam stworzony, nie może stworzyć sobie Boga. Nie może go sobie wyrzeźbić, czy też ulepić z gliny. Bóg, który stworzył świa, nazwany został wcześniej 7 imionami, które określają Jego wielkość: Bóg”, „Ten, który jest”, „Organizator”, „Władca”, „Ten, który świat uczynił”, „Twórca Początków” (,Źródło początku”) ${ }^{39} \mathrm{i}$ „Twórca Rodzajów” (,Sprawca istnienia”). Nie może zastąpić Go idol, wizerunek, posąg, choćby najbardziej utytułowanego ziemskiego władcy. Odniesienie do posągu władcy czczonego w świątyniach $(14,17)$ jest kolejną wskazówką, co do usytuowania Księgi Mądrości w czasie. Umieszczenie posągów cesarza Kaliguli w synagogach rozpoczęło bowiem rozruchy w Aleksandrii. „Te synagogi, których nie mogli spalić ani zniszczyć, ponieważ w ich sąsiedztwie mieszkało mnóstwo Żydów, sprofanowali w inny sposób, z pogwałceniem naszych praw i obyczajów: we wszystkich wznieśli wizerunki Gajusza, a w największej i najczcigodniejszej z nich kwadrygę z brązu". ${ }^{40}$

Kult wizerunków, tak ostro krytykowany w Księdze Mądrości, stał się punktem zapalnym w relacjach społeczności żydowskiej z cesarstwem. Od poddanych rzymskich wymagano bowiem, by ubrani $w$ białe szaty $z$ wieńcami na głowach i śpiewając hymny składali ofiary z kadzidła albo ze zwierząt przed posągiem cesarza boga-zbawcy. Ceremonia składania ofiar cesarzowi mogła odbywać się $\mathrm{w}$ dowolnej świątyni przed wizerunkiem aktualnie panującego cesarza - rzeźbionym lub malowanym - albo w specjalnej świątyni cesarskiego kultu tzw. cezarejonie lub sebastejonie. ${ }^{41}$

Do czasów cesarstwa Żydzi praktykowali tylko tzw. akty dziękczynne wobec cesarzy, wysokich urzędników i innych dobroczyńców. Mogły one przybierać różne formy: dedykowanie synagogi

39 „Źródło piękna”, wg przekładu: R. P o p ow s k i (tłum., wstęp, przyp.), Septuaginta czyli Biblia Starego Testamentu wraz z księgami deuterokanonicznymi i apokryfami, Prymasowska Seria Biblijna 41, Warszawa 2013.

40 Filon z Aleksandrii, Poselstwo do Gajusza, 134.

${ }^{41}$ Por. Swetonius z, Żywotycezarów, II98; IV22; Filon z A lek s a ndrii, Poselstwo do Gajusza, 149-151. 
panującemu władcy, np. Ptolemeuszowi III Euergetesowi; ustawienie w synagogach przedmiotów wotywnych na cześć cesarza, takich jak pozłacane tarcze, wieńce, kolumny, inskrypcje z imieniem cesarskim lub uchwalenie dekretu honoryfikacyjnego w intencji dobroczyńcy, który powinien być uroczyście wręczony przez specjalną delegację. ${ }^{42}$

Natomiast za cesarstwa Żydzi znaleźli się w szczególnie kłopotliwej sytuacji, ponieważ ze względu na zakaz w Prawie Mojżeszowym nie mogli ani składać ofiar w sebastejonach, ani umieszczać wizerunków w swych synagogach. Taka właśnie postawa Żydów mogła zostać uznana za przejaw bezbożności, a ta była ścigana przez prawo rzymskie jako przestępstwo polityczne. Cesarze August i Tyberiusz odnosili się z wyrozumiałością do specyfiki żydowskiej religii, nie żądając stawiania swoich wizerunków w synagogach, natomiast cesarz Kaligula, przewrażliwiony na punkcie kultu własnej osoby, kategorycznie domagał się od Żydów erygowania posągów, najpierw w synagogach w Aleksandrii (38 r. po Chr.), potem w adytonie świątyni jerozolimskiej. Przywódcy Aleksandryjczyków, Izydor i Apion, oskarżali Żydów przed Kaligulą, że nie składają mu ofiar jako bogu, ani nie stawiają posągów. ${ }^{43}$ Taka właśnie postawa Żydów wywołała niezadowolenie cesarza, który miał wobec Aleksandrii własne plany. „Gdy Kaligula usłyszał od niego [Izydora] o narodzie Żydów, który jako jedyny na całym świecie nie chce oddawać mu czci boskiej, oburzył się na tak potworną bezbożność i od tej pory nienawidził całej tej nacji” - wspomina Filon. ${ }^{44}$ Ta właśnie nienawiść do Żydów okazywana przez Kaligulę umożliwiła pierwszy w dziejach pogrom społeczności żydowskiej w Aleksandrii w 38 r. Wrogość ta miała swoje podstawy w planach cesarza, który chciał uczynić z Aleksandrii stolicę cesarstwa. ${ }^{45}$

42 E. O s e k, Wprowadzenie, przekład i komentarz do dzieła Filona z Aleksandrii „Flakkus”, s. 130.

${ }^{43}$ Filon z Aleksandrii, Poselstwo do Gajusza, 76-139, 149, 184-189, 355; J. F l a w i u s z, Przeciw Apionowi, II 73.

44 Filon z A le ks and ri i, Poselstwo do Gajusza, 114-119, 133, 170-171,176$-177,180$.

45 Tamże, 338; J. F 1 a w i u s z, Starożytności żydowskie, XIX 81. 


\section{Zamiary cesarza Kaliguli wobec Aleksandrii}

Cesarz Kaligula pragnął ustawić swój posąg w świątyni jerozolimskiej i tam odbierać boską cześć. Przyjaciel Kaliguli, król Agrypa I, który był Żydem z pochodzenia, przerażony tym projektem cesarza, w długim liście zaklinał go, by anulował decyzję (wrzesień-październik 38 r. po Chr.). Cesarz wstrzymał decyzję, ale ogłosił, że wszyscy Żydzi, którzy znieważą jego posągi poza Jerozolimą, będą podlegać karze śmierci. Jak przypuszcza Filon, cesarz liczył na to, że sprowokuje tym i Żydów, i pogan do podjęcia pewnych kroków, które dostarczą mu pretekstu, by mógł powrócić do pierwotnego planu. ${ }^{46}$ A był to plan podróży na Wschód, do Aleksandrii przez Jerozolimę, podczas której miał tam zawieźć wykonany potajemnie w Rzymie ogromny, z pozłacanego brązu, swój wizerunek i uroczyście erygować go w świątyni jerozolimskiej, a ją samą przekształcić w największe na świecie sanktuarium Gajusza, Nowego Objawionego Zeusa, pod tym bowiem wezwaniem pragnął być czczony. ${ }^{47}$ Sądząc, że tę proklamację najlepiej przyjmie miasto, które kochał - Aleksandria miał zamiar pozostać w nim tak długo, jak tylko będzie to możliwe, myślał nawet o przeniesieniu się tam na stałe i uczynieniu z miasta stolicy cesarstwa. ${ }^{48}$ Wszystkie te plany, na których realizację tak bardzo liczyli Aleksandryjczycy, zostały udaremnione 24 stycznia 41 r. po Chr. przez zamach stanu, w którym Gajusz Kaligula zginął z ręki oficera własnej gwardii pretoriańskiej. ${ }^{49}$

„Kult bożków niegodnych nazwania - to początek, przyczyna i kres wszelkiego zła" $(14,27)$ - podsumowuje autor Księgi Mądrości, przeciwstawiając idolatrię wierze w prawdziwego, jedynego Boga. Wydarzenia, które były kontekstem Księgi Mądrości, są tego jawnym dowodem. Jeśli jednak chodzi o kult bożków - tych wyrzeźbionych

46 Filon z Aleksandri i, Poselstwo do Gajusza, 261-329, 334-336.

47 Tamże, 172-173, 250-253, 337, 346.

48 Tamże, 338; J. F 1 a w i u s z, Starożytności żydowskie, XIX 1-115.

49 E. O s e k, Wprowadzenie, przektad i komentarz do dzieła Filona z Aleksandrii „Flakkus”, s. 48-49. 
z drewna czy ulepionych z gliny - są to idole, bezradne, martwe, niezdolne do poruszania się, bezsilne. Jeżeli jednak chodzi o kult posągów, i to panującego władcy, sprawa jest inna: niebezpieczna, ponieważ urażony władca może się mścić. „Na rozkaz władców czczono posągi - pisze autor w Księdze Mądrości - nie mogąc z powodu odległego zamieszkania czcić ich osobiście, na odległość ludzie odtwarzali postać, sporządzając okazały wizerunek czczonego króla, by nieobecnemu schlebiać gorliwie, tak jak obecnemu" $(14,17)$. Zdecydowane i konsekwentne odmawianie przez naród izraelski oddawania boskiej czci posągom rzymskiego cesarza Kaliguli umożliwiło antyżydowskim frakcjom w Aleksandrii wrogie działania. Członkowie innych społeczności nie mieli takich oporów jak Żydzi.

Cesarz wiedział, że spośród jego poddanych w prowincjach wschodnich najbardziej oddani sprawie kultu cesarskiego byli Aleksandryjczycy, którzy przywykli do deifikacji królów ptolemejskich przez 300 lat ich panowania i przejawiali gotowość do składania ofiar Augustowi i członkom jego rodziny. ${ }^{50}$ Wstąpienie na tron Kaliguli, syna uwielbianego Germanika, przyjęto w Aleksandrii entuzjastycznie. Wysłani do Rzymu członkowie aleksandryjskiej geruzji powitali go jako „boga świata i władcę miasta”, zaś młody cesarz w dowód sympatii dla Aleksandrii kazał przenieść stamtąd do Rzymu obelisk z Heliopolis i ustawić go w cyrku na Watykanie (obecnie Obelisk Watykański na Placu św. Piotra w Rzymie). Właśnie wtedy lider Aleksandryjczyków, Izydor, będący w świetnych układach z nowym cesarzem, postanowił wykorzystać nadarzającą się okazję i otrzymać wreszcie to, co uważał za swój polityczny priorytet: możliwość prześladowania Żydów. Aleksandryjczycy zrozumieli, że cesarz poprze ich antyżydowskie działania. Ten akt bezprawia, jakim było zniszczenie synagog lub sprofanowanie przez ustawienie w nich posągów cesarza, wydarzył się po raz pierwszy, odkąd Żydzi zamieszkali w Aleksandrii i spotkał się z aprobatą Kaliguli. ${ }^{51}$

50 Filon z Aleksandri i, Poselstwo do Gajusza, 137-139.

${ }_{51}$ Tamże, 132-134, 138-148, 164; E. O s e k, Wprowadzenie, przekład i komentarz do dzieła Filona z Aleksandrii „Flakkus”, s. 47. 
Wyjaśnienie, dlaczego Izraelici nie chcieli oddawać boskiej czci cesarzowi Kaliguli, znajduje się w wersetach 15,1-6, w których Izraelici wyznają, że nie chcą złamać zawartego z Bogiem przymierza. Naród wybrany stwierdza z dumą, że nie uległ idolatrii i nie oddawał czci boskiej wizerunkom cesarza. Izrael wyszed zwycięsko z próby.

\section{Reinterpretacja Księgi Wyjścia - jako polemika $\mathrm{z}$ antyżydowską historią Egiptu}

Rozdziały 10-19 są reminiscencją świetnej przeszłości Izraela. Jest tu zachowany podział na sprawiedliwych i bezbożnych. Księga Wyjścia interpretowana jest tak, by ukazać działanie Bożej Mądrości w historii Izraela. Najbardziej wyeksponowany został przykład Księgi Wyjścia, co w kontekście prześladowań wydaje się oczywiste. Żydzi znowu potrzebują wyzwolenia z niewoli egipskiej, która stała się dla nich ziemią uciemiężenia. Ale w kontekście historyczno-religijnym ma on też inne, bardzo istotne znaczenie. Po Aleksandrii krążyły różne interpretacje wyjścia Izraelitów z Egiptu. Uczeni zgromadzeni przy Muzejonie, m.in. Manaseas, retor z Rodos, Apoloniusz z Molon czy Aleksandryjczyk Lizymach, wspierali agitację przeciwko Żydom przez wprowadzenie do swojej historii Egiptu parodii Księgi Wyjścia. Opierali się przy tym na dziele egipskiego kapłana Manetona (początek III w. przed Chr.), w którym Izraelici przedstawieni zostali jako grupa trędowatych wypędzonych z Egiptu. Takie pogłoski krążyły też po Rzymie i można je odnaleźć w dziełach Tacyta, Lukiana i Apiona. ${ }^{52}$

52 P. Kow a 1 i k, Reinterpretacja tekstu o Abrahamie z Rdz 11,27 - 25,18 w Septuagincie, Częstochowa 2010, s. 46.

Apion z Aleksandrii, grecki retor i gramatyk, z pochodzenia Egipcjanin, autor 5-tomowej historii Egiptu, który później przeniósł się do Rzymu, był szczególnie zawziętym wrogiem Żydów. Napisana przez niego historia Egiptu była plagiatem dzieła Manetona, zawierała nie tylko fałszywie przedstawioną interpretację Księgi Wyjścia, przedstawiającą Żydów jako lud trędowatych, zmuszonych do opuszczenia Egiptu, ale ataki na żydowską religię, ich obyczaje i obrzędy. Działalność Apiona 
Ataki na Żydów w Aleksandrii skończyły się właściwie tak szybko, jak się rozpoczęły. Co potwierdza, że był to zorganizowany atak greckich bojówek. Jednak wzajemne animozje i zadrażnienia trwały nadal.

\section{Wymierzenie sprawiedliwości}

Przedstawiony Boży sąd odbywa się w wyobraźni autora księgi. Czy tu, na ziemi, sędziowie ziemscy wymierzyli sprawiedliwość?

W 39 lub 40 r. po Chr. obie skłócone społeczności Aleksandrii grecka i żydowska - wysłały poselstwa do Rzymu. Delegacji żydowskiej przewodniczył Filon Aleksandryjski, który chciał przestawić cesarzowi skargę dotyczącą pogromu Żydów w 38 r. po Chr. i żądać zrównania w prawach z Aleksandryjczykami. Na czele delegacji Greków stał Apion i oskarżał Żydów przed cesarzem o nieoddawanie czci bogom. Przebieg poselstwa znany jest z dzieła Filona Poselstwo do Gajusza. Żydom nie udało się nic wskórać u Kaliguli, który rozgniewany tym, że nie chcą go uznać za bóstwo, nie dopuścił ich w ogóle do głosu.

Tak przebieg poselstwa opisuje Józef Flawiusz: „Tymczasem [39/40 n.e.] doszło do zatargu między zamieszkałymi w Aleksandrii Żydami i Grekami. Obie strony wybrały po trzech posłów i wysłały do Gajusza. W liczbie posłów wysłanych przez Aleksandryjczyków był niejaki Apion, który obsypywał Żydów rozmaitymi oszczerstwami,

miała bardzo szeroki zasięg ponieważ pełnił funkcję rektora Muzejonu i jeździł do Grecji i Italii z wykładami m.in. o greckiej poezji i literaturze jednocześnie podkładając antyżydowską propagandę. Jednak wiele z jego zarzutów opiera się na prawdzie, m.in. te, które dotyczą żydowskich obrzędów, braku praw obywatelskich, krytykowania bogów egipskich i nieuznawanie kultu władcy. Ale między nimi są też oszczerstwa: oskarżenie o tzw. onolatrię, czyli czczenie oślej głowy, oraz rytualne składanie ofiar z ludzi. Szczególne oburzenie, a nawet pewną wesołość, wywołał wśród Żydów absurdalny zarzut, że raz do roku tuczą i zjadają jednego Greka. Jego dzieła nie zachowały się do dziś, ale oskarżenia te znane są z apologetycznego traktatu Józefa Flawiusza, Żyda również pochodzącego z Aleksandrii, który tak jak Apion przeniósł się do Rzymu. 
zarzucając im, między innymi, że nie oddają należycie czci Cezarowi. Gdy bowiem wszyscy poddani państwa rzymskiego stawiają Gajuszowi ołtarze i świątynie i w ogóle oddają mu cześć boską, to sami tylko Żydzi uważali za hańbę wznosić mu posągi i przysięgać na jego imię. Z takimi to i innymi przykrymi oskarżeniami wystąpił Apion, myśląc, jak można było oczekiwać, że rozgniewa Gajusza. W tenczas stojący na czele poselstwa żydowskiego Filon, brat Aleksandra alabarchy, mąż słynący z wielu przymiotów i wykształceń w filozofii, gotował się do wystąpienia, aby odeprzeć zarzuty, lecz Gajusz nie pozwolił mu ust otworzyć rozkazując precz odejść sprzed jego oblicza, a tak bardzo był rozgniewany, iż nikt nie wątpił, że srogo Żydów ukarze. Filon dotknięty zniewagą, odszedł i powiedział do towarzyszących mu Żydów, aby byli dobrej myśli, bo Gajusz wprawdzie okazał im swój gniew słowami, a w rzeczy samej uczynił Boga swym wrogiem". ${ }^{53}$

Użyte tu przez Józefa Flawiusza słowa: „Uczynił Boga swoim wrogiem" niezwykle obrazowo streszczają tę właśnie część Księgi Mądrości, która zawiera opis prześladowania człowieka sprawiedliwego i Bożej interwencji, która ma nastąpić.

Natomiast według danych historycznych na wiadomość o śmierci Kaliguli (41 r.) w Aleksandrii doszło do zamieszek między Żydami i Grekami. Ludność żydowska, która za jego rządów była poniżana i wycierpiała wiele krzywd ze strony Aleksandryjczyków, chwyciła za broń. ${ }^{54}$ Starotestamentalna zasada, kto czym grzeszy, tym bywa karany, znowu została uruchomiona.

Czy o takim zakończeniu myślał autor Księgi Mądrości?

53 J. F 1 a w i u s z, Dzieje Izraela, 8,1.

54 W lutym 41 r. po Chr.; zob. te n ż e, Starożytności żydowskie, XIX, 278279. Nowy cesarz, Klaudiusz, nakazał stłumić te zamieszki: „Powiem wam więc po prostu, że jeśli nie zaprzestaniecie tych ohydnych wzajemnych napaści, będę zmuszony pokazać wam, do czego jest zdolny dobrotliwy władca, gdy wprawi się go w straszny gniew"; List Klaudiusza do Aleksandryjczyków, 80 w: F i 1 o n z Aleks andrii, Flakkus, s. 184. 
Na pewno nie. Księga Mądrości zaliczana jest bowiem do tzw. praeparatio evangelica, ${ }^{55}$ czyli językowego, ale przede wszystkim duchowego przygotowania świata na przyjęcie Ewangelii. A więc właśnie odchodzi tej od zasady Starego Testamentu. Z Księgi Mądrości promieniuje moc przebaczenia. W pięknej skierowanej do Boga-Stwórcy modlitwie autor - z myślą o prześladowcach - wyjaśnia główny cel księgi: „By wyzbywszy się złości, w Ciebie, Panie, uwierzyli" $(12,2)$

ks. Bogdan PONIŻY

55 Termin pochodzi od tytułu dzieła Euzebiusza z Cezarei. 